\title{
Bergsoniana
}

1 | 2021

Reassessing Bergson

\section{The Duration of History in Bergson}

Caterina Zanfi

\section{(2) OpenEdition}

\section{Journals}

Electronic version

URL: https://journals.openedition.org/bergsoniana/435

DOI: 10.4000/bergsoniana.435

ISSN: $2800-874 X$

\section{Publisher}

Société des amis de Bergson

\section{Electronic reference}

Caterina Zanfi, "The Duration of History in Bergson ", Bergsoniana [Online], 1 | 2021, Online since 01 July 2021, connection on 08 November 2021. URL: http://journals.openedition.org/bergsoniana/435; DOI: https://doi.org/10.4000/bergsoniana.435

$\mathrm{BY}$

Les contenus de la revue sont mis à disposition selon les termes de la Licence Creative Commons Attribution 4.0 International. 


\title{
THE DURATION OF HISTORY IN BERGSON
}

\author{
Caterina ZANFI
}

\section{Is There a Philosophy of History in Bergson?}

Bergson has often been criticised for not thinking history. Although he developed one of the most relevant philosophies of time of the last century, his rare statements on history are said to betray an impoverished sense of properly historical issues. Moreover, this criticism is made concerning both his consideration of history as the becoming of human reality and his consideration of historical knowledge and narrative — of both history and historiography.

It was first articulated in the 1930s by Marxist intellectuals like Paul Nizan (who was to perish in the fight against Nazism in 1940). In 1932, Nizan published a polemic entitled The Watchdogs against the so called "Philosophers of the Established Order." There he includes Bergson among the philosophers who are "against history" (Nizan 1965, 29), ${ }^{1}$ considering him incapable of understanding the time and space in which philosophical ideas arise and therefore lacking in sensitivity for the material and embodied aspects of the historical becoming of philosophy. Max Horkheimer, too, during the first stage of his exile from Nazi Germany in Paris in 1933, wrote a rather polemic review of the Two Sources of Morality and Religion for the Zeitschrift für Sozialforschung. The impressionist origins of Bergson's philosophy, he notes, prevented him from understanding the fundamental dynamics of propulsion or retardation in history, although this might

1. Nizan's philosophical judgement, as in that of most French intellectuals of his generation, was shaped by what he saw as a political fault: Bergson's support of French mobilisation during the First World War. 
well be what governs "the dialectic between closed and open societies" (Horkheimer 1988).

Even more incisively, Jean Hyppolite, in his Introduction to Hegel's Philosophy of History, stated in 1948 that "from Descartes to Bergson, French philosophy has always rejected history" (Hyppolite 1983, 94). And one year later, in a lecture at the First Argentinian National Congress of Philosophy, he turned more specifically to Bergson's philosophy of history. His judgment, made from an existentialist point of view, was quite negative:

Perhaps he has yielded too much to this fundamental orientation of his thought: 'Philosophy should be an effort to go beyond the human state,' going from biological human to superman [surhomme] without stopping long enough at the figures of human historical existence that lie between the two (Hyppolite 1950, 921).

Most $20^{\text {th }}$-century readers shared this kind of perspective, still present today: ${ }^{2}$ even if they acknowledged Bergson's philosophy of duration to be deeply connected with the philosophy of life and of nature, they often complained about its excision of history in its properly human and cultural dimension. In a discussion about Bergson and history published in the fourth volume of Les Etudes bergsoniennes in 1956, even Raymond Polin and Raymond Aron refused to acknowledge an authentic philosophy of history in Bergson (Polin 1956; Aron 1956). Aron in particular disqualified Bergson's theory of history, in which he found no room for the vocation of humanity to be realised. Nonetheless, Aron had referred to a number of Bergsonian ideas in his doctoral dissertation, Introduction à la philosophie de l'histoire, published in 1938. Bergson himself read the thesis and wrote a grateful letter to Aron, praising his historiographical use of the concepts of découpage and retrospection, whose Bergsonian inspiration was evident (Bergson et al. 2002, 1595; see also Aron 1938).

A similar criticism of Bergson's theory of history can be found in a French thinker who was very close to Bergson and deeply immersed in his philosophy, Maurice Merleau-Ponty. His criticisms against Bergson mainly belong to the first phase of his work and were particularly explicit in the first phenomenological texts. In a later phase, in essays like In Praise of Philosophy (Merleau-Ponty 1988) and The Visible and the Invisible (Merleau-Ponty 1968), Bergson became instead a rather positive reference, both for the development of his philosophy of perception and visibility,

2. The same disappointment with Bergson's philosophy of history is present in the recent Ph.D. thesis by Mélanie Weill (2019). 
and for the elaboration of a "new ontology." Even then, when Bergson's thinking was being thoroughly reassessed, Merleau-Ponty saw in Bergson's philosophy of history a line he could not cross. In an essay of 1947, The Metaphysical in Man, he criticized Bergson pointing at the generality of his description of the world, and to his theory of history:

And if, on the other hand, his philosophy is finally to be understood as a philosophy of immanence, he may be reproached with having described the human world only in its most general structures (e.g., duration, openness to the future); his work lacks a picture of human history which would give a content to these intuitions, which paradoxically remain very general (Merleau-Ponty 1964b, 97).

In the lecture course on nature he gave at the Collège de France, MerleauPonty acknowledged that Bergson was thinking a limited Absolute in the natural domain but asserted this not to be the case in the historical domain. According to Merleau-Ponty, there was in Bergson no "historical inscription," no "calling and responding generations," only a "heroic appeal from individual to individual, a mystique without a 'mystical body" (Merleau-Ponty 1964a, 188). The reassessment of Bergson's philosophy seemed to positively invest the intuition of duration and of life but couldn't afford the philosophy of The Two Sources and in particular its philosophy of history. It was precisely the tension with this aspect of Bergsonian thought that nourished Merleau-Ponty's philosophy of history in the 1950s, along the lines of his reflections on expressivity and the institution (Belot 2006; Caeymaex 2017). For Merleau-Ponty — who was seeking a history "in the making" (se faisant), a positive evaluation of the social and impersonal dimension, prior to the personal dimension - Bergson could not offer a satisfactory model for the philosophy of history:

During the long years he was preparing the Two Sources, he does not seem to have impregnated himself with history as he had with life; he did not find 'complementary powers of understanding' on terms with our own duration, working in history as formerly he had found them working in life (MerleauPonty 1964a, 188).

Today, however, when the separation between nature and culture, and between nature and history, has come into crisis, ${ }^{3}$ it is possible to reconsider the philosophy of history in Bergson's work (and especially in his last work,

3. The need for a redefinition of history in the context of today's planetary crisis has been given in the clearest and strongest way by Chakrabarty (2009), and reiterated in a Bergsonian context in the discussion with Frédéric Worms at the Penn State conference on Global Bergsonism in November 2020. See also the very Bergsonian remarks on history in the context of the recent pandemic events in Worms (2021). 
The Two Sources), and to assess its fertility in today's debate. Does Bergson really have such a compromised relationship with history? Is he really insensitive to the specificity of the historical dimension, as Hyppolite, Polin, Aron, and others claim? And does he really remain trapped in an individualist spiritualism that prevents him from grasping the properly historical collective dimension, as Merleau-Ponty asserts?

Or is he instead trying to define history in a new way that cannot be found in the traditional opposition to the sciences of nature, a new way that - because of its novel and nuanced approach — might be fertile in understanding today's planetary historical crisis?

\section{History as the Domain of Freedom}

When we look at the earliest references Bergson makes to the philosophy of history, we find a rather traditional distinction between history and nature that parallels the distinction between freedom and necessity, consciousness and matter.

Bergson begins the 1911 Oxford lecture, "The Perception of Change," by tracing this parallel:

What holds good for the present of the individuals, holds also for the present of nations: an event belongs to the past, and enters into history when it is no longer of any direct interest to the politics of the day and can be neglected without the affairs of the country being affected by it (Bergson 2009a, 169; 1946, 179).

Past and present, like memory, probably work for the individual as well as for the collectivity. Like consciousness, history belongs to the domain of freedom. Bergson soon developed this idea further in a talk he gave in 1913 following his election as president of the London Society for Psychical Research, "Phantasms of the Living' and 'Psychical research." After voicing a rather surprising support for the analogy between psychic and natural phenomena, arguing that both are subject to laws, Bergson distinguishes these types of facts from the facts that belong to history. $\mathrm{He}$ affirms the heterogeneity of historical and natural phenomena:

History does not repeat itself. The battle of Austerlitz was fought once, and it will never be fought again. It being impossible that the same historical conditions should ever be reproduced, the same historical fact could never be repeated; and as a law expresses necessarily that to certain causes, always the same, there will correspond effects, also always the same, history, strictly speaking, has no bearing on laws, but on particular facts and on the no less particular circumstances in which they were brought to pass (Bergson 2009b, 64; 1920, 78-79). 
Negating historical laws and their rootedness in life, Bergson confirms the separation - widely discussed in Germany in the preceding decades between the so called Naturwissenschaften and Geisteswissenschaften. This division was defended by neo-Kantian philosophers in particular. Thinkers such as Heinrich Rickert and Wilhelm Windelband affirmed the radical heterogeneity of history and the natural sciences with the same arguments Bergson employs in his 1913 lecture. Indeed, Bergson's definition seems literally to cite one of the central theses advance by Windelband, who considered history an idiographic science, dealing with singular and unique facts, and defined the natural sciences as nomothetic sciences, searching for laws, repetitions, and causal relations (Windelband 1924). This analogy between Bergson and the historicist positions of the Heidelberg neoKantians, however, might be deceiving because it follows the introduction Windelband wrote to the German translation of Matter and Memory, published by Diederichs in 1909. ${ }^{4}$ The Heidelberg professor presented Bergson's philosophy as a French answer to the dominance of scientism and naturalism. The German answer to the same problem, on this reading, were the historical sciences. Windelband also noted that the key concept of Bergson's philosophy of duration, denying the idea of the repetition of the "identical," was the "event." With this term — Geschehen in German - Windelband referred to the singular and irreplaceable event and at the same time alluded to the category of history, Geschichte, which in German has the same root.

\section{The "Law" of History}

In his 1932 book The Two Sources of Morality and Religion, Bergson returns to the concept of history and develops it in much greater detail. In his definition, he abandons once and for all any affinity with neo-critical systems, like Windelband's, in which history is guided by transcendental values. Bergson's research led him to develop a philosophy of history consistent with his empirical approach and with his own philosophy of duration. In The Two Sources, there are epistemological analogies of history with his duration-based psychology and biology, as well as ontological analogies of historical time with duration and evolution, all traced back to a single creative movement. Bergson's philosophy of history now allows for thinking the metaphysical unity of nature and history: the extension

4. Windelband 1908. These pages were removed from subsequent editions of Materie und Gedüchtnis starting in 1919. For the history of the translations and the reception of Bergson's works in Germany see Zanfi (2013a). 
of the logic of continuity and becoming from life to history establishes a homogeneity between the logic of life and the logic of human actions.

The law of history Bergson introduced in The Two Sources is not separate from the biological domain but instead refers directly to the law of dichotomy expounded in Creative Evolution, ${ }^{5}$ which it shifts from the original biological perspective to a historical perspective.

In the last chapter of the 1932 work, Bergson enquires into the reasons for the frenetic course of industrial development in his time and introduces the notion that historical development is characterised by a bidirectional tendency. ${ }^{6}$ In history, the spiritual and material progress of humanity alternate: each of these tendencies must push itself to its extreme before it is overtaken by the other, which in turn is pushed to the extreme before being overtaken as well, and so on.

Bergson identifies two opposing trends, one leading to simplicity and the other to complication, one to sobriety and the other to luxury. The former is a tendency of moral development, the latter of technical development. Bergson refers to this opposition as the dichotomy of mechanics and mysticism - hence the rather enigmatic title of the fourth and last chapter of the book: "Final Remarks: Mechanics and Mysticism."”

Bergson thus interprets the materialistic frenzy he observes in the 1930s as the culmination of one of the two directions of human development, which will be followed by the resumption of spiritual and moral development. In short, historical development in Bergson follows a dichotomous course modelled on the biological law that governs the evolution of nature. The Two Sources articulates the union of human history and natural social history in its formulation of the "law of double frenzy" that explains the

5. This law summarises the divergent paths taken by evolution - from plant to animal and from animal to human being; see Bergson (1911, $111 \mathrm{ff})$.

6. Philippe Soulez traces the genesis of the philosophy of history from a biological scheme back to the need to find a way out of the situation in which modern industrial civilisation finds itself: "since humanity is stuck at an impasse, a guiding principle must be found that allows for thinking, against the backdrop of discontinuity, the continuous sequence history makes legible that has given rise to industrial society but to do so without renouncing the idea of conserving what has been gained along the way" (Soulez 1989, 294).

7. For an interpretation of this unusual dichotomy, see Zanfi (2013b). Rates (2017) addresses the articulation of the philosophy of technology and history in Creative Evolution, and places the topic within a broader discussion of the concepts of nature and culture in the thesis (Rates 2019). 
movement of the "habits of life," of its "vital tendency" (Bergson 2008, $313 ; 1935,282)$.

To introduce this law, Bergson recalls "alternations of ebb and flow in history" (Bergson 1935, 286). The phrase echoes the "corsi e ricorsi" or cyclical recurrences of Giambattista Vico, whom Jules Michelet, another protagonist in the anti-Cartesian line of French philosophy, translated into French in 1835 (Vico 1835). Bergson moreover insists that recourse to the term "law" is neither a concession to determinism or finalism, nor does it imply historical fatalism:

We do not believe in the fatality of history. There is no obstacle which cannot be broken down by wills sufficiently keyed up, if they deal with it in time. There is thus no unescapable historic law. But there are biological laws; and the human societies, in so far as they are partly willed by nature, pertain to biology on this particular point. If the evolution of the organized world takes place according to certain laws, I mean by virtue of certain forces, it is impossible that the psychological evolution of individual and social man should entirely renounce these habits of life (Bergson 2008, 312-313; 1935, 253).

Laws of this kind only admit of an imperfect but nonetheless "sufficient regularity" in the becoming of human societies.

\section{The Fatality of Progress}

Bergson's idea of time-invention contradicts the idea of historical fatality. There is no teleology, no determinism, no eschatological tendency — all of them essential assumptions in most philosophies of history. Instead, as Raymond Aron notes in his dissertation, Bergson founds his philosophy of history on the notion of a retrospective illusion of fatality.

All retrospective judgements are illusions: what he theorised for the intellect can also be applied in the domain of historical knowledge, Bergson argues in the introductions to The Creative Mind. Historical fatality only appears from the point of view of the observer who has already lived, not from the point of view of the one who lives. As duration, and as life, history is a succession of unpredictable novelty. That is why, when he introduces the image of the oscillatory movement of human history, the illustration Bergson chooses is not the image of a pendulum but that of spiral movement: ebb and flow have memory, and their movements never completely overlap, precisely because they explain the development and growth of the original tendency they express: the pendulum is endowed with memory, and is not the same when it swings back as on the outward 
swing, since it is then richer by all the intermediate experience. This is why the image of a spiral movement, which has sometimes been used, is perhaps more correct than that of the oscillations of a pendulum.

In a 1930 essay on "the tragedies of progress" that Bergson quotes in The Two Sources, Gina Lombroso describes a similar oscillatory movement but paints the alternation of material and moral progress in more sombre tones. For her, "every civilisation is made up of various tendencies, each of which, after a certain period of development, exhausts its force of ascent and, after a more or less extended period of stasis, passes into descent, which movement is almost always contemporary with an evolution in another field." On this basis, she defines progress as a "sinuous march" similar to movement of growth in the human organism. ${ }^{8}$ According to Lombroso, the problems of contemporary industrialism cannot be overcome through a return to an alleged origin. Like the movement of life, the dual movement of history - be it a sinus wave, a polarised spiral, an alternation of ebb and flow - involves growth that takes place in the emergence of new historical circumstances that are just as unrepeatable as the ones that preceded them. For Bergson, there are two models for this movement. On the one hand, there is biology: "There is thus no unescapable historic law. But there are biological laws; and the human societies, in so far as they are partly willed by nature, pertain to biology on this particular point." On the other hand, there is memory: "the pendulum is endowed with memory" (Bergson 2008, $313 ; 1935,252)$. Not only the directions of the evolution of life but, more profoundly, the rhythm of duration envelop human history.

Bergson's theory seems indeed to amalgamate cyclical visions of history with linear visions and to exorcise the risks of each: the repetition of the identical cyclical history implies, and the finality of progress linear history implies.

In this framework, the frequent references in The Two Sources to the historical experience of the First World War and its lessons are significant: Bergson reflects on his contemporaries' clear perception of the risk of a catastrophe, of annihilation, and of its deep connection with our own technological nature and attitude of exploitation. Already in Creative Evolution, intelligence was considered a vital faculty developed to survive and to master matter. And although intelligence contributes to the evolution of life and its tools can produce new feelings and new possibilities for our consciousness, fabrication entails great risks for humanity. Machines meant

8. Bergson quotes the French translation (Lombroso 1931) in Bergson (2008, 318; 1935, 258). The essay has also been translated into English (Lombroso-Ferrero 1931). 
to liberate us can actually come to dominate us, and our historical horizon is not free of disaster: humanity cannot take any future for granted.

After the catastrophe of the First World War and the frenzy of industrial development in the 1920s, Bergson was more conscious than ever of the fragility of civilisation and of the insecurity of the human condition in the world. This only bolstered his abandonment of any comforting optimism that would count on the realization of a cosmic or historical order. In 1932, Bergson's vision of history implies a radical disillusion about the idea of continuous progress.

Despite the possible threats considered in the last chapter of The Two Sources in particular, Bergson's philosophy does not imply any nostalgic retreat to a lost, happier, and safer time, any primitivist temptation, any nostalgia for a lost origin, for a lost paradise of any kind. And this is perfectly consistent with his refusal to project a final, absolute liberation. There has never been an original paradise and there will never be a paradise at the end of times. Such theories would imply a teleology and dualism in which mechanics and mysticism would be opposites. In the final chapter of The Two Sources, both are on the contrary considered means of liberation for humanity. But this liberation, this "progress" is never completed. There is a call and a need for creation which prevents any static achievement — anything "tout fait," as Bergson would have said.

Bergson's philosophy of history, like his cosmology, presumes neither an origin nor a finality: there is neither creation ex nibilo (there is no nibil.) nor is there room for messianic hope. In Bergson's thought, eternity would coincide with the process of temporal creation. The Absolute is in the making, it is duration. In the domain of the philosophy of history, this strict refusal of determinism and of finality represents the end of an illusion of security and of a number of optimistic myths that characterised $19^{\text {th }}$ century philosophy and culture, not only in their dialectic and positivist versions but in spiritualist faith in a providential order of history or in a finality of nature as well.

Despite his opposition to fatality and finality, Bergson keeps referring to "progress": even in history, even in the law of double frenzy, the "struggle" between the moral and the material impulse is said to be but a "superficial aspect of an advance" (Bergson 2008, 317; 1935, 257). What kind of advance and progress does Bergson have in mind? 
Charles Péguy, in Clio, his essay on history written 1909-1913 (and thus long before the publication of The Two Sources) and published after his death, lays out a similar vision of progress:

The modern world finds itself here, contemplates and takes pleasure in itself, cherishes itself in one of its essential institutions [...] [T] his theory of progress essentially comes down to a savings bank theory. It supposes, it creates an automatic little intellectual savings bank for each of us, automatic in the sense that we always pay in and never withdraw (Péguy 1942, 48-49).

The modern idea of progress is linked to the bourgeois idea of saving, and it contradicts the very workings of nature, which as it advances expends and wastes a part of itself: "Nature, as you know, reality, the organic, too, is governed by another law. There is loss, perpetual privation, wear, inevitable friction, which is in no way accidental but part of the game, of the rules of the game" (Péguy 1942, 49-50). Péguy's philosophy of history was not just influenced by Bergson's theory of memory (Creyghton 2011), but also by Bergson's philosophy of life, as exposed in Creative Evolution. $\mathrm{He}$ juxtaposes the modern and distorted idea of historical progress with the rhythm of Bergsonian duration:

That is progress, as they say. But I know that there is an entirely different time, that the event, reality, the organic follows an entirely different time, follows a duration, a rhythm of duration, which must be called Bergsonian duration because it was he who discovered this new world, this eternal world (Péguy 1942, 52).

Yet, as Raymond Polin remarks in his 1956 essay, progress in Bergson's thinking has a double meaning: (1) progress as a principle of foresight, as the development of a prior direction, a fatal destiny of historical becoming, a notion Bergson opposes as a version of finality; (2) and a sort of "open progress," which Bergson endorses, that allows for a movement of growth, an evolution, an advancement of civilisation (Polin 1956, 33). In keeping with his philosophy of duration, this is a discontinuous, undetermined progress, defined by creative acts and the diffusion of mystic love.

\section{History of Humanity and History of Nature}

Such a philosophy of history, which might seem reduced to the psychological theory of memory and duration as well as to the model of biological evolution, also has a profound impact on Bergson's anthropological position. Introduced in the biological framework of Creative Evolution as a living species, humanity is first of all one species among all the others. Even if Bergson defines humanity differently than he does other species - 
because of its intelligence, its language, and its aptitude for fabrication and social life - humanity remains a biological species.

Bergson also insists on the continuity between natural history and human history, despite the saltus the human species has taken. But he insists just as strongly that naturalism does not apply in the field of history: there is no history before there are humans; animals, for example, do not have history. One reason is that the law of two-fold frenzy differs slightly from the law that governs evolution:

[I]n the general evolution of life, the tendencies thus created by a process of dichotomy are to be found in species different from one another; they have set forth, each independently, to seek their fortunes in the world; and the material form they have assumed prevents them from reuniting to bring back again, stronger than it was, more complex, more fully evolved, the original tendency. Not so in the evolution of the psychical and social life. Here the tendencies, born of the process of splitting, develop in the same individual, or in the same society. As a rule, they can only be developed in succession (Bergson 2008, 314; 1935, 254-255).

There is, however, another reason that distinguishes human history from the history of life in general: the special role of individuals in history. The past that precedes humanity is marked by the appearance of new species, and only with humanity do we witness a historical development: the history of this particular species developing through the ages, marked by events and by the lives and achievements of individuals. History concerns humanity alone. Raymond Aron stresses the political significance of the role The Two Sources attributes to individuals in history:

Perhaps the existence of a few people is the supreme achievement, if it is in them and in them alone that spirit finally overcome nature. A direct line would then lead from Time and Free Will to The Two Sources: the consciousness of the individual is the true history: duration against space, love against social servitude. We have no right to despair of societies since the hero sweeps them up in charging the heavens, no right to trust them since the weight of the past and of collective necessities leads them back to their nature - which is enjoyment and combat (Aron 1956, 50-51).

It nevertheless deserves emphasising that even great individuals cannot do without a collective effort and without conveying their emotion to a group - be it a small monastic community or an international organisation like the League of Nations. History is inextricably personal and impersonal, subjective and epochal. An individualistic reading of The Two Sources would be partial. 
This aspect of Bergson's last book is not new: the inseparability of individuality and collectivity in historical movements reflects the heterogeneity of temporal rhythms Bergson described in earlier works. In Matter and Memory, materiality is not extraneous to duration, and already in Creative Evolution technical objects, which impact communities, participate in duration and gain significance in historical becoming. Probably the most important step toward the considerations on "mechanics and mysticism" in The Two Sources is the passage on the steam-engine in Creative Evolution: Newcomen's invention marks one of the decisive today we would say "disruptive" — moments in human history, an event that shapes its age more than any other:

In thousands of years, when, seen from the distance, only the broad lines of the present age will still be visible, our wars and our revolutions will count for little, even supposing they are remembered at all; but the steam-engine, and the procession of inventions of every kind that accompanied it, will perhaps be spoken of as we speak of the bronze or of the chipped stone of prehistoric times: it will serve to define an age (Bergson 2007, 139-140; 1911, 146).

This closer look at Bergson's philosophy of history thus does not simply correct some misunderstandings, according to which he would have excised history from his philosophy or centered his theory of history on the role of individuals. It also reveals a philosophical and cultural significance that speaks to us today. This is particularly the case for the articulation of history and nature, as Jean Hyppolite remarked as early as 1949 in his Argentina lecture:

Bergson's philosophy is a philosophy of life before it is a philosophy of human history. Bergson's concepts, élan vital, creative evolution, dichotomy and double frenzy, suit life and are not specifically tailored to the history of humanity, as they are in Hegel's Phenomenology of Spirit, for example. Bergson, in contrast, shows us the relationship between human history and the general evolution of life, between civilisation and nature (Hyppolite 1950, 915).

The great novelty of Bergson's philosophy, especially when we consider the cultural atmosphere of his time, consists precisely in the articulation of human history and the general evolution of life, of the two realms of history and nature, or of civilization and life.

On the one hand, Bergson seems to borrow the laws of history from nature. Yet the link between history and nature is not an extension of the principle of deterministic causality to the level of history; on the contrary, he contests the validity of such a principle on the very level of nature 
itself. The recognition of regularity at the natural and the historical level cannot be reduced to a naturalistic position in the sense in which the term naturalism was used in the $19^{\text {th }}$ century. In acknowledging the evolutionary character of history and in referring to the law of dichotomy, Bergson does not describe an automatic oscillation or an eternal repetition of the same course of events, but rather a creative spiral movement that cannot go back and take the same steps once more.

On the other hand, the evolution of life itself seems to be deeply historical. While Bergson's philosophy of evolution inspires his philosophy of history, there is also, as Jean Hyppolite remarked, "a historical aspect of evolution, which does not actualise a ready-made plan" (Hyppolite 1950, 915). Bergson himself makes the same point in a letter to Harald Höffding in 1915:

The essential argument I aim at mechanism in biology is that it does not explain how life unfolds a history, that is to say, a succession in which there is no repetition, in which every moment is unique and bears in itself the representation of the whole past (Bergson 1972, 1149).

To appreciate the novelty of Bergson's solution, we must not forget that philosophy in his time was in crisis, under pressure from the natural sciences as well as the social sciences that emerged from $19^{\text {th }}$-century positivism. At its most influential, positivism in the footsteps of Spencer considered biological evolutionism to be the key to interpreting every domain of human psychological and social life. Like some of the most advanced European philosophers, Bergson tried to find a way to pass between the Scylla of naturalism and Charybdis of metaphysics. Bergson avoids on the one hand Croce's historicist idealism, according to which anything can be subsumed under human thought and everything has an historical dimension, as if there were no world but the human world, and as if even nature had history. Bergson also, and most importantly, avoids the objectivation, the naturalization of history, opposing the rather crude and naif attitude of Spencerian social scientists who used physiological laws to justify all social and cultural phenomena. Both sets of arguments, idealist and naturalist, existed alongside the distinction between history and nature. With his effort to embed nature and history in the more comprehensive category of life, Bergson's position also differs from contemporary German organic vitalism, and from a demonism of power opposed to reason and ethics. Bergsonian biology - biology in the "very wide meaning it should have" (Bergson 1935, 82) — brings together morality, history, culture, 
and sociology, and his philosophy of life comprehends both the closed tendencies toward war and conservation, and the open tendencies toward peace and creation.

If there is no full-fledged philosophy of history in Bergson, that is because he abandons the traditional distinction between nature and history: his comprehensive philosophy of life has embedded this duality in a biological movement of creation that can explain the shared evolution of nature and humanity. This theoretical shift seems to anticipate the evolution of contemporary historiography. Especially in the last thirty years, as awareness of the climate crisis has grown, the duality of nature and history has become increasingly obsolete, which poses a "challeng[e to] our capacity for historical understanding," as Chakrabarty observes. The modern, Viconian-Hobbesian humanist separation between natural history and human history that was commonplace until the nineteenth and even into $20^{\text {th }}$ century, has now collapsed. The awareness that humanity is a "geological force" and the emergence of new fields of research such as environmental history require historians, as well philosophers, to put "global histories" - especially of the last three centuries - "in conversation with the species history of humans" (Chakrabarty 2009, 201, 207).

And that, precisely, was what Bergson laid out: a history in which there is no divorce from our living background, which does not believe us capable of completely abandoning our natural conditions, in which the "laws" of history reflect the movement of the evolution of life; and also, a history propelled by the actions of great human individuals as well as by nonhuman agents such as technical objects and conditions of access to natural resources. Deploying the richness of durée on the level of history, Bergson points to a way of understanding history in its vital and widest meaning: as the memory of the world.

\section{Bibliography}

Aron, Raymond. 1938. Introduction à la philosophie de l'histoire, essai sur les limites de l'objectivité historique. Paris: Gallimard.

Aron Raymond. 1956. "Note sur Bergson et l'histoire." In Les Études bergsoniennes 4, 41-51. Paris: A. Michel.

Belot, David. 2006. “'Un tableau de l'histoire humaine' : Merleau-Ponty au-delà de Bergson.” Archives de Philosophie 69(1): 79-100.

Bergson, Henri. 1911. Creative Evolution. Translated by Arthur Mitchell. London: Macmillan \& Co. 
Bergson, Henri. 1920. Mind-Energy, Lectures and Essays. Translated by H. Wildon Carr. New York: H. Holt and Co.

Bergson, Henri. 1935. The Two Sources of Morality and Religion. Translated by Ruth Ashley Audra and Cloudesley Shovell Henry Brereton. New York: H. Holt and Co.

Bergson, Henri. 1946. The Creative Mind. Translated by M. L. Andison. New York: Philosophical Library.

Bergson, Henri. 1972. Mélanges: L'idée de lieu chez Aristote, Durée et simultanéité, correspondance, pièces diverses, documents. Edited by André Robinet. Paris: Presses universitaires de France.

Bergson, Henri. 2002. Correspondances. Edited by André Robinet. Paris: Presses universitaires de France.

Bergson, Henri. 2007. L'Évolution créatrice. Paris: Presses universitaires de France.

Bergson, Henri. 2008. Les Deux sources de la morale et de la religion. Paris: Presses universitaires de France.

Bergson, Henri. 2009a. La Pensée et le mouvant : essais et conférences. Paris: Presses universitaires de France.

Bergson, Henri. 2009b. L'Énergie spirituelle. Paris: Presses Universitaires de France.

Caeymaex, Florence. 2017. "A propos de l'émotion créatrice: vie, institution et histoire dans Les Deux Sources." In Annales bergsoniennes VIII : Bergson, la morale, les émotions, edited by Arnaud François and Camille Riquier, 205-236. Paris: Presses Universitaires de France.

Chakrabarty, Dipesh. 2009. "The Climate of History: Four Theses." Critical Inquiry 35 (2): 197-222.

Creyghton, Camille. 2011. “'Histoire, mémoire de l'humanité'. L'influence de Bergson sur la conception de l'histoire et celle de la mémoire de Charles Péguy." L'Atelier du Centre de recherches historiques. Revue électronique du Centre de recherches historiques [online] 7.

Horkheimer, Max. 1988. "Zu Henri Bergsons Les Deux Sources de la morale et de la religion [1933]'. In Gesammelte Schriften, edited by Alfred Schmidt, 3:106-109. Frankfurt am Main: Fischer.

Hyppolite, Jean. 1950. "Vie et philosophie de l'histoire Chez Bergson." In Actas Del Primer Congreso Nacional de Filosofia (Mendoza 1949) 2: 915-921. 
Hyppolite, Jean. 1983. Introduction à La Philosophie de l'histoire de Hegel. Paris: Seuil.

Lombroso, Gina. 1931. La Rançon du machinisme. Paris: Payot.

Lombroso-Ferrero, Gina. 1931. The Tragedies of Progress. Translated by Coley Taylor. New York: E.P. Dutton and Company.

Merleau-Ponty, Maurice. 1964a. "Bergson in the Making." In Signs, 182191. Evanston, IL: Northwestern University Press.

Merleau-Ponty, Maurice. 1964b. “The Metaphysical in Man.” In Sense and Non-Sense, translated by Hubert L. Dreyfus and Patricia Allen Dreyfus, 83-98. Evanston, IL: Northwestern University Press.

Merleau-Ponty, Maurice. 1968. The Visible and the Invisible: Followed by Working Notes. Northwestern University Press.

Merleau-Ponty, Maurice. 1988. In Praise of Philosophy and Other Essays. Evanston: Northwestern University Press.

Péguy, Charles. 1942. Clio. Paris: Gallimard.

Polin, Raymond. 1956. "Y a-t-il chez Bergson une philosophie de l'histoire ?” In Les Études bergsoniennes, 4, 9-40. Paris: A. Michel.

Rates, Bruno Batista. 2017. "Vie et histoire humaine dans L'évolution créatrice de Bergson." In Das Leben im Menschen oder der Mensch im Leben? Edited by Thomas Ebke and Caterina Zanfi, 369-379. Potsdam: Potsdam University Press.

Rates, Bruno Batista. 2019. "Natureza e cultura na filosofia de Bergson.” São Carlos: Universidade Federal de São Carlos.

Soulez, Philippe. 1989. Bergson politique. Paris: Presses universitaires de France.

Vico, Giambattista. 1835. Oeuvres choisies de Vico. Edited by Jules Michelet. Paris: L. Hachette.

Weill, Mélanie. 2019. "Bergson et la Grande Guerre. Une généalogie contextualisée des Deux Sources de la morale et de la religion.” $\mathrm{PhD}$ dissertation. Louvain: KU Leuven.

Windelband, Wilhelm. 1908. "Zur Einführung." In Materie und Gedächtnis. Essays zur Beziehung zwischen Körper und Geist, III-XIV. Jena: Diederichs.

Windelband, Wilhelm. 1924. "Geschichte und Naturwissenschaft." In Präludien. Aufsätze und Reden zur Philosophie und ihrer Geschichte, 136-160. Tübingen: J.C.B. Mohr (Paul Siebeck). 
Worms, Frédéric. 2021. Vivre en temps réel. Paris: Bayard.

Zanfi, Caterina. 2013a. Bergson et la philosophie allemande: 1907-1932. Paris: Armand Colin.

Zanfi, Caterina. 2013b. "La machine dans la philosophie de Bergson." In Annales bergsoniennes, IV: 275-296. Paris: Presses universitaires de France.

Caterina Zanfi is a researcher at the CNRS in the laboratory Pays germaniques - Transferts culturels (École normale supérieure, Paris) and she is President of the Société des amis de Bergson. She is the author of Bergson, la Tecnica la Guerra (2009) and Bergson et la philosophie allemande (2013). Her areas of research are the philosophy of life in Europe in the early $20^{\text {th }}$ century and philosophical anthropology.

\begin{abstract}
Although he developed one of the most important modern theories of time, Bergson has often been criticised for not thinking history. Drawing on his writings from Creative Evolution to The Two Sources, I show that, on the contrary, he was trying to define history in a new way, one that would not be exhausted by the traditional opposition to the natural sciences. Bergson's new philosophy of history, free of teleology and determinism, allows us to think the specificity of the human historical dimension without erasing its articulation with natural evolution. Against the critical readings Aron and Merleau-Ponty have offered, I maintain that Bergson's philosophy does not withdraw into an individualist spiritualism but includes the collective dimension and the history of non-human, both natural and technological, reality.
\end{abstract}

Keywords: Henri Bergson, philosophy of history, philosophy of nature, anthropology, Maurice Merleau-Ponty, Charles Péguy.

Résumé : Bien qu'il ait développé l'une des théories du temps les plus marquantes de la modernité, on a souvent reproché à Bergson de ne pas avoir pensé l'histoire. En nous appuyant sur ses écrits, de L'Evolution créatrice aux Deux Sources, je montre qu'il cherchait plutôt à définir l'histoire d'une manière nouvelle, qui pourrait ne pas se retrouver dans l'opposition traditionnelle aux sciences de la nature. La nouvelle philosophie de l'histoire de Bergson, libérée de la téléologie et du déterminisme, nous permet de penser la spécificité de la dimension historique de l'homme sans effacer son articulation avec l'évolution naturelle. Contredisant les lectures critiques d'Aron et de Merleau-Ponty, la philosophie de Bergson n'est pas enfermée dans un spiritualisme individualiste, mais inclut la dimension collective et l'histoire de la réalité non humaine — tant naturelle que technologique.

Mots-clés : Henri Bergson, philosophie de l'histoire, philosophie de la nature, anthropologie, Maurice Merleau-Ponty, Charles Péguy. 
